should have ceased to function after such a short life. In October 1946 a new county Society was formed under the old name. The reports for 1946 and 1947 indicate that the Society has made a good start under Mr. Oliver Pike's presidency and should soon gain its rightful place among similar county societies in Britain. Copies of the Society's journals may be obtained from 11 The Avenue, Flitwick, Bedfordshire.

\section{Breeding of Locusts for Research and Instruction}

THE supply of living animals for both teaching and research purposes is a perennial problem for zoological laboratories. The new insecticides are partly responsible for the difficulty which has occurred in recent years in obtaining adequate supplies of cockroaches. For many purposes the locust can take the place of the cockroach, and it has the advantages of being larger, easy to rear in laboratory conditions and, for such a large animal, it has a very rapid life-cycle; the whole life-cycle takes about seven weeks, and only about half that time is required from hatching to the emergence of the adults. Instructions for the breeding and rearing of locusts have now been prepared by the AntiLocust Research Centre, and copies can be obtained from the Director of the Centre, British Museum (Natural History), London, S.W.7. The Centre is not prepared to sell locusts to anyone, but it will supply them free for certain research projects and, so far as possible, for starting stocks for teaching purposes; adults for class dissection will not be sent.

\section{The Physical Society: Annual Exhibition}

THE Physical Society's Annual Exhibition of Scientific Instruments and Apparatus will be held during April 5-8, 1949, in the Physics Department of the Insperial College of Science and Technology, South Kersington. The sessions during which the Exhibition will be open are: April 5, 2-9 p.m. ; April 6, 10 a.m. -1 p.m., 2-9 p.m.; April 7 and 8, 10 a.m.1 p.m., 2-7 p.m. During the Exhibition the following discourses will be delivered: "Some Problems of Wave Diffraction in the Ionosphere", by Mr. J. A. Ratcliffe; "Some Modern Aspects of Scientific Instruments", by Mr. A. J. Philpot; "A Review of the Methods and Instruments used in Energy Measurements of Particles in Atomic Nuclei", by Prof. O. R. Frisch. A film on the liquid idophor or teleidoscope will be shown. The Exhibition will also display entries for the craftsmanship and draughtsmanship competition, which is being revived after a lapse during the war years. This competition is organised to encourage and give recognition to skill and ability in craftsmanship and draughtsmanship among apprentices and learners in the instrument-making industry, and a large number of firms and technical institutions is supporting it. The prize-winning entries will afterwards be shown in the Science Museum at South Kensington.

\section{Managènent Bulletin}

From December 1948 the British Institute of Management has been issuing to members and subscribers a Maglagement Bulletin concerned with events in the Bum arement field as a whole. The first issue inclids a f st of forthcoming events as well as papers anthed by the Institute for February-May, 1949, with brief notes on the activities of the education department, examinations department and the information and research department, and a list of recent additions to the library. Suggestions and criticisms with regard to the scope and utility of the Bulletin are invited.

\section{Seventh Pacific Science Congress}

The Seventh Pacific Science Congress (see Nature, September 11, p. 409) is now in session in New Zealand. Thirty countries are participating, and of these the seventy-one United States representatives form a particularly large delegation. These American men of science are representing not only the United States but also the dependent territories, such as the Pacific Islands and Honolulu, and the occupation authorities in Japan. British and American civil air-lines and also the United States Military Air Transport Service have made special arrangements to fly these American delegates from their respective scattered locations to New Zealand. The Royal Society has sent a delegation of six to the Congress (Nature, January 1, p. 17).

\section{Announcements}

Prof. Pitrre-Paul Grasse has been elected a member of the Section of Anatomy and Zoology of the Paris Academy of Sciences, in succession to Dr. Zobert Courrier, who has become one of the permanent secretaries of the Academy.

THE Institute of Metals Medal (in platinum) for 1949 of the Institute of Metals has been awarded to Dr. Wriliam Hume-Rothery, lecturer in metallurgical chemistry in the University of Oxford, in recognition of his outstanding contributions to the science of non-ferrous metallurgy.

PROF F. F. NORD, of the Department of Organic Chenistry, Fordham University, New York, has been aydrded the 1949 Carl Neuberg Medal of the American Society of European Chemists and Pharmacists.

ProF. K. S. Dodns, head of the Department of Botany and Genetics at the Imperial College of Trgpical Agriculture, Trinidad, has been appointed principal scientific officer of the Empire Potato Collection, Commonwealth Bureau of Genetics, Cambridge.

Mr. W. K. B. Marshall has been appointed assistant Airector of research of the British Welding Reseaych Association. Mr. Marshall is well known for his work on light alloy and stainless steel welding, and in his new position he will pay particular attention to non-ferrous welding research.

THE gfficers for 1949 of the Nairobi Scientific and Philosbphical Society (see Nature, October 23, p. 647) arg: President, V. A. Beckley ; Vice-Presidents, Dr. B. A. Keen, Dr. R. M. Dowdeswell and H. E. Watson.

THE Institute of Navigation has arranged a symposjim on "Operational Aspects of Marine Radar", to be held at the Royal Geographical Society on frebruary 18, at 2 p.m., under the chairmanship of Sir Robert Watson-Watt. Papers to be presented include two from the U.S. Institute of Navigation. The meeting is open to non-members.

The W. H. A. Robertson Medal and Premium will be awardgd annually by the Institute of Metals to the author or authors of the best paper contributed to the Journal of the Institute of Metals on engineering aspects of non-ferrous metallurgy. For the first award, papers published in the Institute's Journal from March 1948 to August 1949, inclusive, will be considered. 